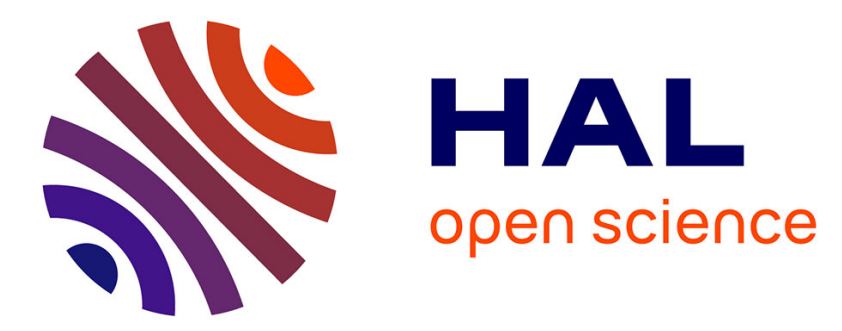

\title{
Knowledge engineering approach for the analysis of viticulture
}

Bernard Kamsu-Foguem, Aurélie Flammang, Germaine Tchuenté Foguem

\section{To cite this version:}

Bernard Kamsu-Foguem, Aurélie Flammang, Germaine Tchuenté Foguem. Knowledge engineering approach for the analysis of viticulture. Ecological Informatics, 2015, vol. 30, pp. 72-81. 10.1016/j.ecoinf.2015.09.004 . hal-01281986

\section{HAL Id: hal-01281986 \\ https://hal.science/hal-01281986}

Submitted on 3 Mar 2016

HAL is a multi-disciplinary open access archive for the deposit and dissemination of scientific research documents, whether they are published or not. The documents may come from teaching and research institutions in France or abroad, or from public or private research centers.
L'archive ouverte pluridisciplinaire $\mathbf{H A L}$, est destinée au dépôt et à la diffusion de documents scientifiques de niveau recherche, publiés ou non, émanant des établissements d'enseignement et de recherche français ou étrangers, des laboratoires publics ou privés. 


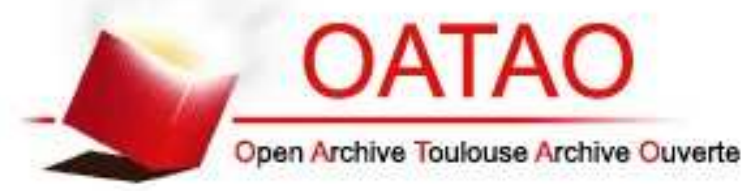

\section{Open Archive TOULOUSE Archive Ouverte (OATAO)}

OATAO is an open access repository that collects the work of Toulouse researchers and makes it freely available over the web where possible.

This is an author-deposited version published in : http://oatao.univ-toulouse.fr/ Eprints ID : 15539

To link to this article : DOI:10.1016/j.ecoinf.2015.09.004 URL : http://dx.doi.org/10.1016/j.ecoinf.2015.09.004

To cite this version : Kamsu-Foguem, Bernard and Flammang, Aurélie and Tchuenté Foguem, Germaine Knowledge engineering approach for the analysis of viticulture. (2015) Ecological Informatics, vol. 30. pp.

72-81. ISSN 1574-9541

Any correspondance concerning this service should be sent to the repository administrator: staff-oatao@ listes-diff.inp-toulouse.fr 


\title{
Knowledge engineering approach for the analysis of viticulture
}

\author{
Bernard Kamsu-Foguem $^{\mathrm{a}, *}$, Aurélie Flammang ${ }^{\mathrm{b}}$, Germaine Tchuenté-Foguem ${ }^{\mathrm{c}}$ \\ a Laboratory of Production Engineering (LGP), EA 1905, ENIT-INPT University of Toulouse, 47 Avenue d'Azereix, BP 1629, 65016, Tarbes Cedex, France \\ ${ }^{b}$ COGESENS, 207 rue Jean Baptiste Charcot, 92400 Courbevoie, France \\ c Département d'Informatique, UMI 209, UMMISCO, Faculté des Sciences, Université de Yaoundé I, B.P. 812 Yaoundé, Cameroon
}

Keywords:

Viticulture

Climatic indexes

Multicriteria analysis

Conceptual graphs

Numerical-symbolic reasoning

\begin{abstract}
A B S T R A C T
The sustainable development of agricultural regions requires a methodical approach that will make a viable land management system policy in practice. In this regard, distinctive contextual characteristics of a country (remarkable areas for raising the regional products) could be taken into account in order to promote the good character of agricultural outputs and to increase the added value of considered lands. The manuscript primarily describes in qualitative and quantitative terms a mechanism for synthesizing information about wine production characteristics and therefore provides sufficient substantive treatment of agricultural or other system interactions. Firstly, the manuscript presents a discussion about many factors that affect wine production, and secondly, the focus is more on the development of an integrated approach using numerical and symbolic reasoning. The Geoviticulture Multicriteria Climatic Classification (MCC) System is engaged with a methodology comprising three viticultural climatic indexes of different natures: hydric type (dryness index), heliothermal type (Huglin index), and Nictothermal type (Cold Night Index). The knowledge representation is symbolized with the conceptual graphs formalism and the reasoning mechanisms are based on graph operations. A visual reasoning development focuses more on the decision process that would seem more appropriate for a practice on decision support. In addition, the Decision Support System (DSS) component is illustrated with a case study of Croatia republic in very broad characterizations of its main regional grape varieties.
\end{abstract}

\section{Introduction}

With the collapse of the Berlin Wall in November 1989, the land policies and land market in Central and Eastern European countries have been evolved through the land reform and the self-regulation of the free market (Bojnec, 2011; Lerman et al., 2002). Furthermore, in July 2013, the accession of Croatia as new member state of the European Union has made it possible to be eligible for assistance of Common Agricultural Policies. Under these circumstances, the European agricultural policies may encourage the development of intensive production practices in fertile regions and extensive farming situations (i.e. abandoned or marginalized farming areas) in regions with limited environmental conditions (e.g. mountainous and isolated areas). This underscores the need of targeting policies in these agricultural landscapes and the importance to highlight the principles and measures that preserve the integrated development with local, regional and national characteristics (Kanianska et al., 2006).

Croatia is a young country; it declared independence in June 1991 and 6 months later obtained diplomatic recognition by the European Economic Community members, and subsequently, the United Nations. However, it is a very old wine country. The country enjoyed a huge renaissance

\footnotetext{
* Corresponding author. Tel.: + 33624302337

E-mail address: Bernard.Kamsu-Foguem@enit.fr (B. Kamsu-Foguem).
}

which allowed a new generation of winemakers to revive an ancient tradition. The vines have grown there since ancient times (Jackson, 2000). It was introduced about five centuries before Christ by the Greeks who planted the first vines in the south of Dalmatia, particularly in the islands of Vis, Hvar, and Korcula. The first experiences were not conducive to any form of culture with their rocky slopes tumbling steeply to an indigo sea and azure sky. In terms of production, with an average overall annual quantity of 1.5 million hectoliters, it arrives at the 21st largest in the world. With over 100 traditional varieties of local grapes listed in a small area, Croatia has a very promising future, especially as the young winemakers are determined to highlight this feature. The strong wine identity of Croatia is a major asset in a market increasingly globalized. Croatia has recently tried to build a strategy and to adapt his business in the field of viticulture and marked the first major breakthrough of Croatian wines on the international scene. This is not surprising, given its extraordinary climatic predispositions and in light of the fact that the Croatia has two great traditional varieties of local grapes, Plavac Mali grape and Malvasia Istarska grape, which have become an essential part of the Istrian peninsula's tourism offerings.

The aim of this paper is to study the Croatian vineyard as a whole and to shed light on its characteristics. Local types of grape varieties are numerous, their characteristics are part of Croatian heritage, but the best known/common varieties are also present in some vineyards. As a first step, we describe the Croatian regions and identify its main 
varieties. Secondly, using Conceptual Graph user interface (CoGui), we will study the different possible combinations of key parameters (soil/climate/varieties) to determine whether the current varieties are the best. We will need accurate data and comparators to know precisely if the conditions are optimal for obtaining a quality of bunch of grapes (Fernández-Mar et al., 2012). Using the business rules, once the procedures are integrated in the CoGui software, we can analyze the choices made by Croatia. As a result, our proposal benefits from a thoughtful combination of thoroughly scheduled sequences of activities and integrated approaches that occur throughout the reasoning process (see Fig. 1). The combination of ontology-aware and applicable data-driven models is an interesting approach to model the domain knowledge and to build the interpretable models (Thomopoulos et al., 2013).

The development of a hybrid numerical-symbolic approach to crop modeling is useful for knowledge specification and reasoning about locations having similar meteorological and agricultural conditions (Russell et al., 1999). Using meteorological data and soil characteristics, it is possible to deduce some properties from contextual information and domain knowledge about the main crop cycles and traditional winemaking present in worldwide with associated specified requirements (Pinney, 2012). In that case, we will develop hypotheses grouping designation, which will enlighten Croatia in their communication to increase their international recognition. The global market is difficult to penetrate; the characteristics of the "Old World" wines and traditions have a leading market share in the key sectors of the international wine economy (Charters, 2006). Given its rich history, varied geography, and diverse culture, Croatia has been mainly influenced by viticulture and winemaking. Some of these characteristics of the country will determine whether its export potential is opened or closed to the

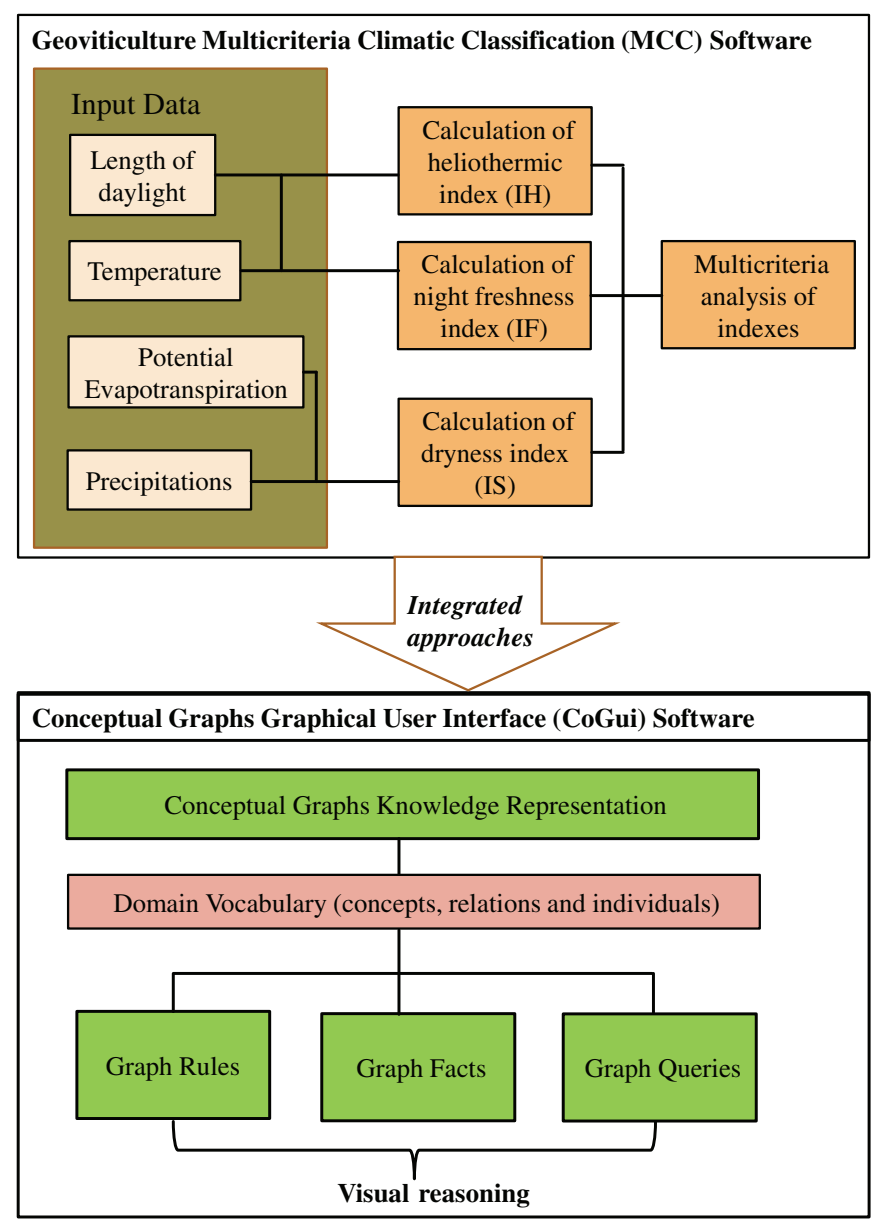

Fig. 1. General scheme of the proposal. current standards of winery business models and marketing practices. Using these results, it is possible to propose appropriate sustainable improvements to access the market without distorting the assets of this country.

In order to make the reading easier, the rest of the document is divided into three sections. Section 2 presents a numerical reasoning with the Geoviticulture Multicriteria Climatic Classification (MCC) System. Section 3 describes a symbolic reasoning with conceptual graphs for formal knowledge representation and visual reasoning (rules and queries). Section 4 provides the conclusion of the hybrid approach combining data-driven models and ontology-based reasoning for the development of sustainable systems, especially for the improvement of viticulture.

\section{Numerical reasoning with MCC system}

\subsection{Geoviticulture Multicriteria Climatic Classification System}

The Geoviticulture Multicriteria Climatic Classification (MCC) System proposes a methodology comprising three viticultural climatic indexes of different natures: hydric type (dryness index) (Deloire et al., 2004), heliothermal type (Huglin index) (Huglin, 1978), and Nictothermal type (Cold Night Index). Each of these indexes is complementary to each other (see Table 1) (Tonietto, 1999). From these clues, classes were created with value intervals or groups for a characteristic. These classes will help consolidate the regions in the world according to some similarities and to provide guidance on places, grape varieties, or numbers of harvests per year. In this case, it is suggested that similar wine production processes be grouped together under the same trading designations. Assessments are based on several climatic variables and agro-climatic indexes (Ruml et al., 2012).

Particularly, each region has been analyzed with a combination of these three major indexes. It is a multicriteria analysis of these three indexes which suggests if a vineyard produces a good wine or not. Of course, we cannot say that a wine is good or not by just these three indexes. There are plenty of other parameters that affect its quality. We have other factors such as the winemaking, wind, maintenance of the vineyard, wine maturation, compliance dates, or the influence of the wine critics or gastronomy critics (Sablayrolles, 2009).

\subsection{Numerical reasoning with the processing of climatic indexes}

For the numerical reasoning (see Fig. 2), we use the procedures implemented in the MCC system available online in the website "cnpuv.embrapa.br" that allows us to directly calculate (see Fig. 3) the useful indexes (Torres et al., 2011). From the point of view of numerical reasoning (Kamsu-Foguem et al., 2013b, 2014c), it is required to find

Table 1

Viticultural climatic indexes of MCC system with their respective classes (Tonietto and Carbonneau, 2004).

\begin{tabular}{llll}
\hline Viticulural climatic indexes & Climate classes & Acronym & Class interval \\
\hline Dryness Index (SI, mm) & Humid & SI-2 & $150<\mathrm{SI}$ \\
& Sub-humid & $\mathrm{SI}-1$ & $50<\mathrm{SI} \leq 150$ \\
& Moderate dry & $\mathrm{SI}+1$ & $-100<\mathrm{SI} \leq 50$ \\
& Very dry & $\mathrm{SI}+2$ & $\mathrm{SI} \leq-100$ \\
Huglin Index (HI) & Very cold & $\mathrm{HI}-3$ & $\mathrm{HI} \leq 1500$ \\
& Cold & $\mathrm{HI}-2$ & $1500<\mathrm{HI} \leq 1800$ \\
& Cool & $\mathrm{HI}-1$ & $1800<\mathrm{HI} \leq 2100$ \\
& Warm & $\mathrm{HI}+1$ & $2100<\mathrm{HI} \leq 2400$ \\
& Hot & $\mathrm{HI}+2$ & $2400<\mathrm{HI} \leq 3000$ \\
& Very hot & $\mathrm{HI}+3$ & $3000<\mathrm{HI}$ \\
Cold Night Index $\left(\mathrm{CI},{ }^{\circ} \mathrm{C}\right)$ & Hot nights & $\mathrm{CI}-2$ & $18<\mathrm{CI}$ \\
& Warm nights & $\mathrm{CI}-1$ & $14<\mathrm{CI} \leq 18$ \\
& Cool nights & $\mathrm{CI}+1$ & $12<\mathrm{CI} \leq 14$ \\
& Cold nights & $\mathrm{CI}+2$ & $\mathrm{CI} \leq 12$ \\
\hline
\end{tabular}




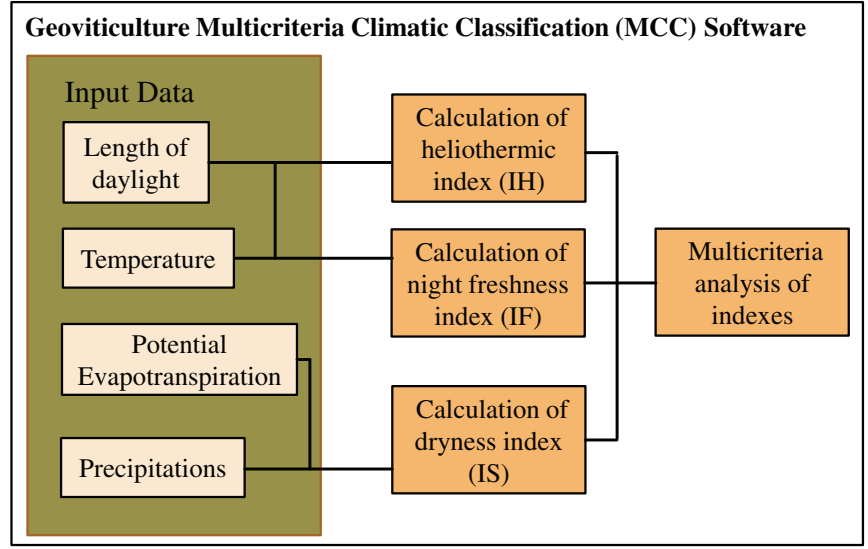

Fig. 2. Numerical reasoning with MCC software.

the similarities between two regions by information management and processing with fuzzy similarity (Paoli et al., 2007).

The exact numerical reasoning can find some similarities if the numbers are equal. But in certain cases, there are slight differences. To remedy this, we believe there would be two options. The first option would be to add a programming software module to process information similarity approached. The second option would be to use index classes. These classes are ranges of values. In our example regarding the viticultural climatic indexes, Dalmatia is characterized by the classes HI, Cl-1, and DI-1 (See Table 1). Las Bruxas being in the same case, then the software can find a similarity and highlights the common features. However, the described classes can still be criticized as being a range of values; a region may have a close indication of another class. In this case, it is possible to find alternative interesting locations in neighbor classes including regions that are similar to the region of interest.

Concerning reasoning with similarities between regions of the world, a problem remains to be settled out about the range of possible values and the probabilities of different values occurring. Since we don't have any potential evapotranspiration data, the DI of each region is anecdotal. MMC procedures allow finding some regions in the world that are similar with those of Croatia, but a more efficient system of reasoning would do away with the perceived dissimilarity. Therefore, we must find the appropriate means to improve the reasoning process. Each comparative analysis should consider not only the geology but also the climate and winemaking practices. It becomes evident that sets of areas have approximately the same viticulural climatic indexes but receive significantly different considerations for vineyards applications. The knowledge generated by primary lessons shows that it would be pertinent to share best practices between similar geographical regions experiencing analogous wine production.

Indeed, the regions of Zagreb and Slavonia have respective index values HI 1877, DI 200, CI 12 and HI 1881, DI 200, CI 13 (very similar indexes). If we compare the varieties by region, five out of seven varieties are the same: Cabernet Sauvignon, Pinot, Cabernet Franc, Chardonnay, and Graševina. Therefore, we can observe a possible link between indexes and varieties. However, the MCC system indicates that Huglin index is only a minimum value for the proper development of a variety, above this value regions are equivalent. It is not just this index that can be critical in distinguishing the wine regions. In addition, the Cold Night Index is a more accurate impact on the quality of a wine (flavors and coloring).

The information we have at our disposal do not allow us to connect a variety of indexes to specific values. We cannot rely on any scientific study to determine the optimal growing method for each variety. So we only compared the regions of Croatia with other wine regions of the world to get an idea of the possible outcomes of the culture of known wine varieties in order to monitor quality standards for products.

\section{Symbolic reasoning with conceptual graphs}

A conceptual graph is a graph with two kinds of nodes respectively called concepts and conceptual relations, and each arc must connect a conceptual relation to a concept (it is said that the graph is bipartite) (Sowa, 1984). Visual reasoning is performed through graph homomorphism which maps adjacent nodes to adjacent nodes and offers the possibilities of specialization of the concept and relation nodes labels (Sowa, 2000). As the saying goes "a picture is worth a thousand words," the visual reasoning by means of conceptual graph operations

Calculation of viticultural climatic indexes $\mathrm{HI}, \mathrm{CI}$ and $\mathrm{DI}$

Instructions: Fill the form below and click on Calculate. The climatic data are for the months of October through March in the Southern Hemisphere or April through September in the Northern Hemisphere.

Identification

Name of the viticultural region:

Name of the weather station:

Country:

Geographic coordinates

Latitude: $\quad \overline{0} \circ \overline{0}, \overline{\mathrm{N}} \quad \overline{\mathrm{O}}$

Longitude:

Altitude:

$\mathrm{m}$

Monthly dimatic data (interannual means: 30 years, if available; minimum 10 years)

\begin{tabular}{|c|c|c|c|c|c|c|}
\hline \multirow{2}{*}{\multicolumn{2}{|c|}{$\begin{array}{c}\text { Month } \\
\text { Hemisphere }\end{array}$}} & \multicolumn{3}{|c|}{ Air temperature $\left({ }^{\circ} \mathrm{C}\right)$} & \multirow{3}{*}{$\begin{array}{l}\text { Precipitation } \\
\begin{array}{c}\text { Monthly total } \\
(\mathrm{mm})\end{array}\end{array}$} & \multirow{3}{*}{\begin{tabular}{|c|} 
Potential evapotranspiration (PET Penman- \\
Monteith)
\end{tabular}} \\
\hline & & \multirow{2}{*}{$\begin{array}{l}\text { Average } \\
\text { minimum }\end{array}$} & \multirow{2}{*}{$\begin{array}{l}\text { Average } \\
\text { maximum }\end{array}$} & \multirow{2}{*}{$\begin{array}{c}\text { Average } \\
\text { mean }\end{array}$} & & \\
\hline Southern & Northern & & & & & \\
\hline October & April & & 0 & $\overline{0}$ & 0 & 0 \\
\hline November & May & & 0 & 0 & 0 & 0 \\
\hline December & June & & 0 & 0 & 0 & 0 \\
\hline January & July & & 0 & 0 & 0 & 0 \\
\hline February & August & & 0 & 0 & 0 & 0 \\
\hline March & September & 0 & 0 & 0 & 0 & 0 \\
\hline
\end{tabular}




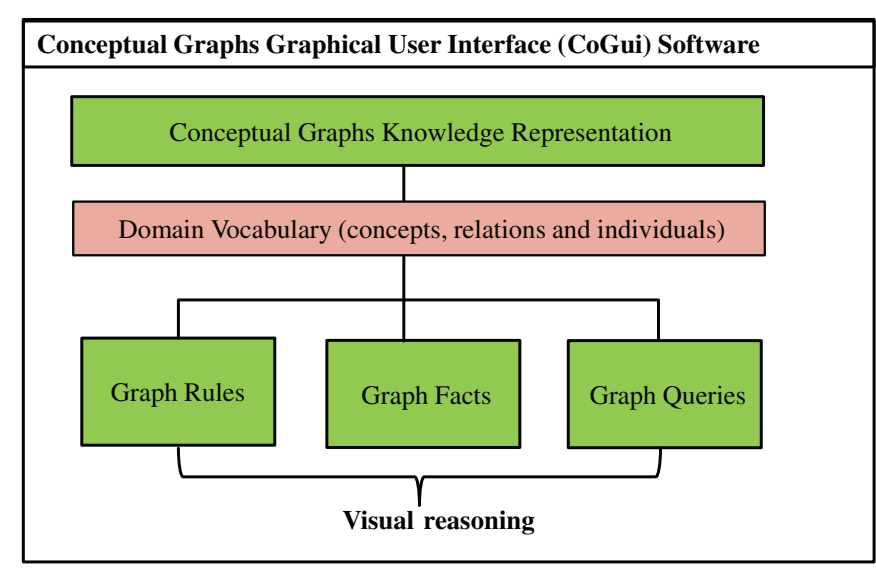

Fig. 4. Symbolic reasoning with CoGui software.

(Baget and Mugnier, 2002) is a magnificent view for the scientific popularization of logical reasoning. Without ruling out the demonstrations by the logical formulas, graph operations are sufficient to explain the visual reasoning process like a diagram that could serve as proof of graphical demonstrations (Chein and Mugnier, 2008).

Once the "algorithmic" rules were established, we need to analyze regions. For this, we decided to implement these rules by using a software tool called Conceptual Graphical User Interface (CoGui) (Carloni et al., 2009). CoGui is graphic design software developed in Java language. This software allows, from a conceptual graph, to establish a link between the different parameters, it is then possible to build some control rules in a visual form with conceptual graphs. Then, we can ask a new structure to analyze and compare the predefined control rules. Thus, the software will investigate whether the structure has similarities with the control rules, and it is possible to draw a conclusion (Genest and Chein, 2005).

This software seems to fit our need, indeed as we have "algorithmic" rules and we can search whether the Croatian regions are capable of receiving a production of French vineyards. Therefore, we simply enter our control rules as means to generate the conceptual graph operations in visual reasoning for the analysis of Croatian regions (Kamsu-Foguem et al., 2008).

Note that the software is only an aid to improve the speed comparisons taking into account all technical, operational, and environmental constraints (Nicholas and Durham, 2012). Adaptive management strategies can allow to stop climatic effects on grapevine performances (Lorenz et al., 1995; Ripoche et al., 2011).

In our context, the reasoning mechanism advocates the use of graph operations (mainly rules application and constraints verification) to analyze a set of facts (Baget et al., 2011). So, it has the ability to select some graphical representation and therefore the provided results highlight relationships that could not be true in a series of charts (Kamsu-Foguem et al, 2013c). In addition, the engaged visual reasoning
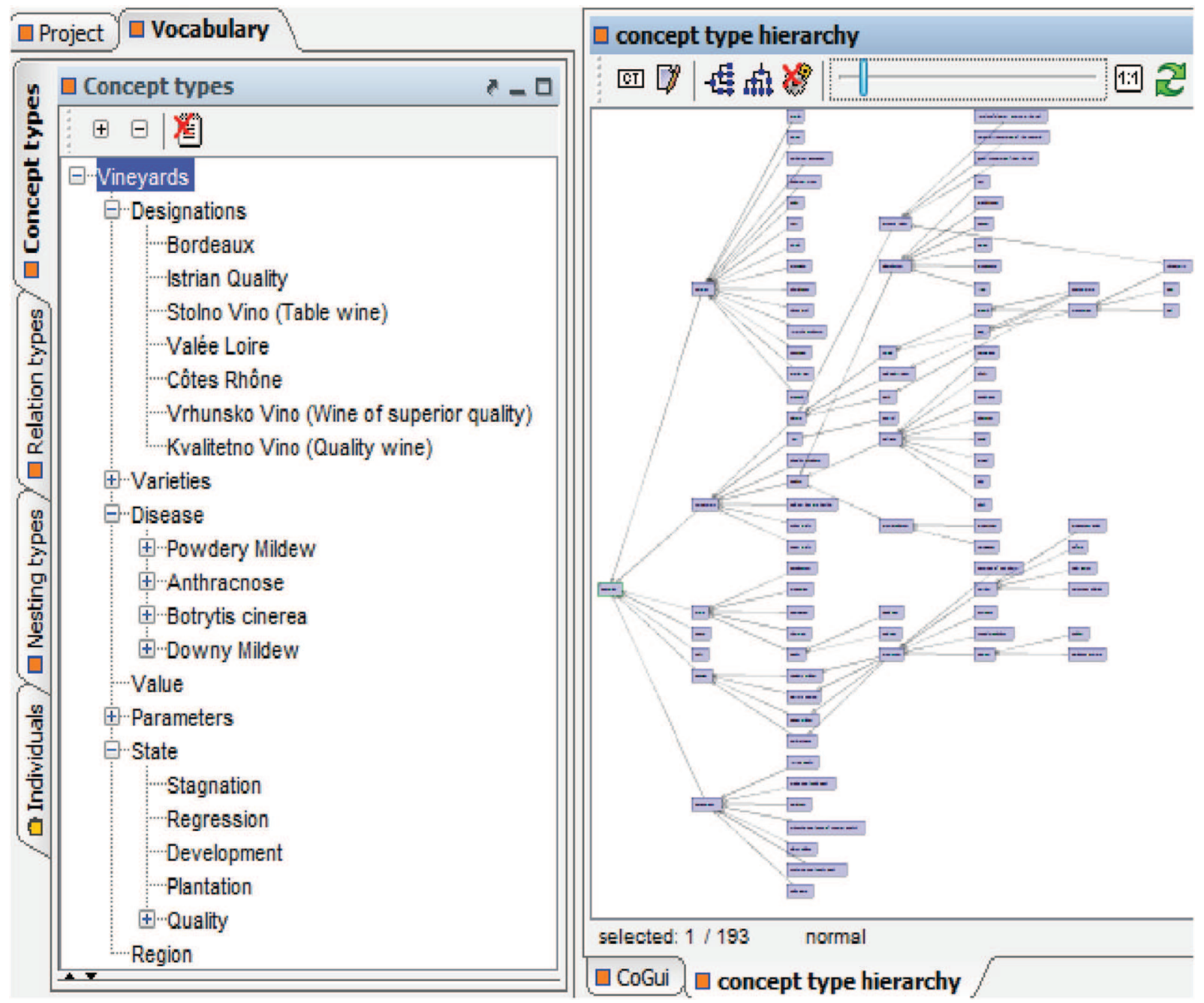

Fig. 5. Partial hierarchy of concepts in the vineyard (tree view and graph view). 


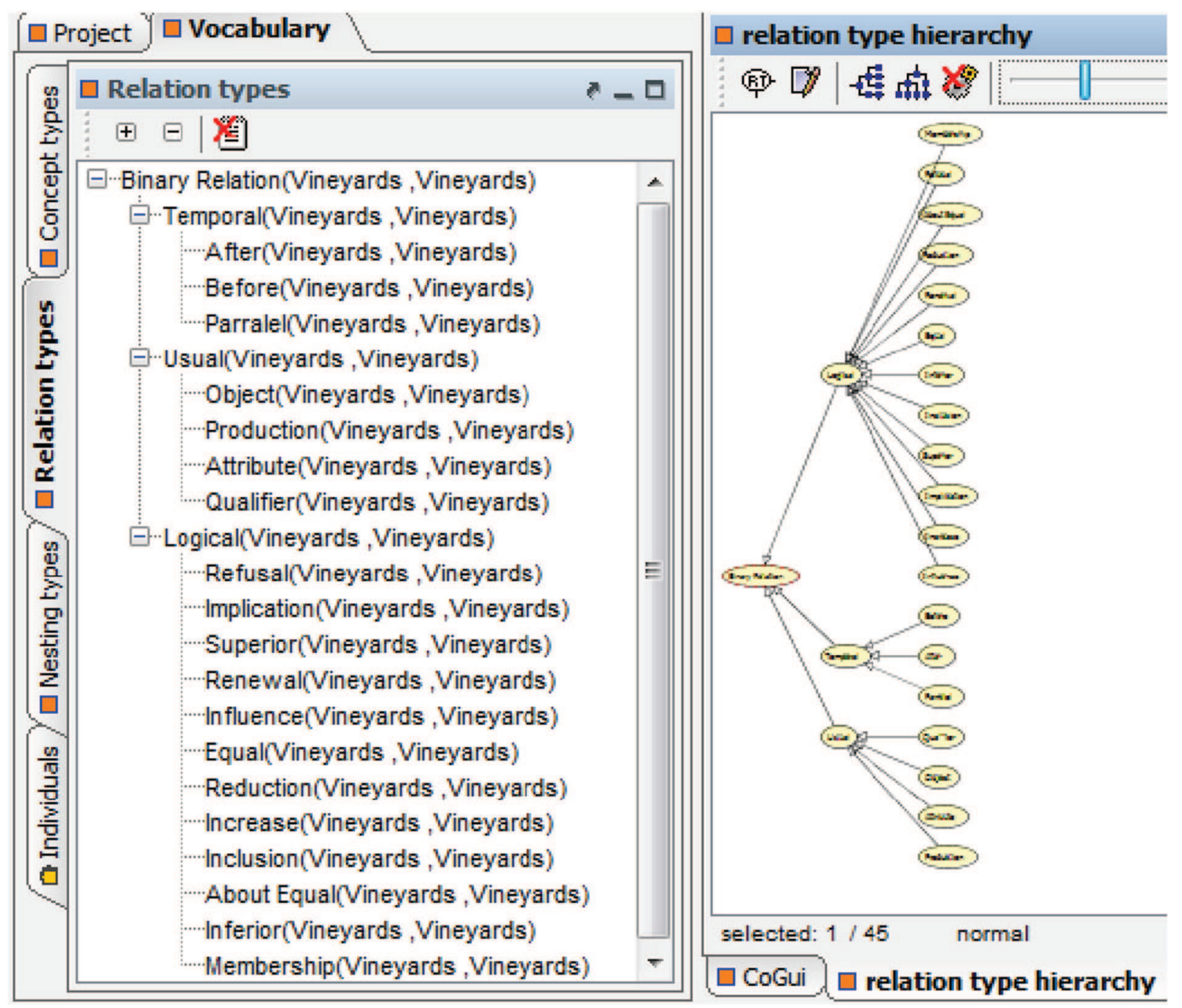

Fig. 6. Hierarchy of conceptual relations (tree view and graph view).

would challenge the relevance, redundancy, or inconsistency of described rules (Kamsu-Foguem, 2012). However, this remains the responsibility of the knowledge engineer for whom it is important to be successful and as faithful as possible to the reality in the study. The management of business rules is done in collaboration with domain experts (Kamsu-Foguem, 2014; Kamsu-Foguem and Abanda, 2015; Kamsu-Foguem and Noyes, 2013; Kamsu-Foguem et al., 2014a,b, 2015; Potes Ruiz et al., 2013, 2014; Sene et al., 2015).

This section is related to symbolic reasoning based on conceptual graph structures and its visual operations (see Fig. 4). We want to know whether a given structure corresponds to some existing ones in the database. So, we must use some automated procedures implemented in the CoGui software. The queries are represented by conceptual graph structures, which we compare to other graphs (facts and rules), recorded in CoGui software. The representation of weakly structured imprecise data enables us to make more flexible comparisons of fuzzy conceptual graphs (Thomopoulos et al., 2003). Then, the software will indicate if the studied structure has similarities (with a given degree) with already modeled graphs, and we will present these similarities. This will also give us an indication of a conclusion to be drawn with regard to the policy on winemaking and respect for local products (Kamsu-Foguem and Flammang, 2014).

\subsection{Concepts categorization}

The first step is to formalize the domain vocabulary with some information associated to usual concept types (see Fig. 5) and common relation types between these concepts.

- During this stage, the various elements of the hierarchized types are organized in order to have consistency in terms.

- In some cases, we can change largely the concept types of the previous project, if we believe that certain categories were not modeled with suitable considerations. For example, we placed the treatment after each disease (Ellison et al., 1998) and not in parallel. We also added numerical data.

- Therefore, we added first most popular varieties that are present in Croatia. Then we added the appellations and some parameters links with appellations.

- Finally, on climate, reorganization was made with the addition of new indexes.

\subsection{Binary relations and numerical data}

Binary relations are used to link two concepts together and are also organized with a hierarchy of types (see Fig. 6). 


\section{CoGui 1.3.7b - Croatian_Wine.cogxml}

File Edit View Graph Reasoning Tools Help

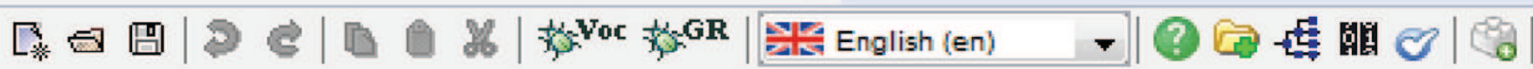

\begin{tabular}{|c|c|c|}
\hline \multirow{5}{*}{ 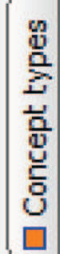 } & \multicolumn{2}{|l|}{$\square$ Individuals } \\
\hline & Name & Privileged type \\
\hline & 2500 & Huglin \\
\hline & 88 & Dryness Index \\
\hline & 11 & Month \\
\hline$\infty$ & 100 & Dryness Index \\
\hline 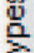 & 5 & Month \\
\hline$\hat{ت}$ & 1886 & Huglin \\
\hline 흠 & 1,6 & Ashes in $g / L$ \\
\hline$\frac{\pi}{\Phi}$ & 7 & Month \\
\hline 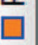 & 3 & Month \\
\hline 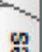 & 3000 & Huglin \\
\hline$\stackrel{\square}{\mathrm{g}}$ & 1801 & Huglin \\
\hline वै & 11,7 & Cold Night Index \\
\hline 舜 & 1686 & Huglin \\
\hline$\frac{d}{2}$ & 10,4 & Cold Night Index \\
\hline ㅁ) & 2 & Month \\
\hline n & 1676 & Huglin \\
\hline & 18 & Sugar in $g / L$ \\
\hline & 160 & Dryness Index \\
\hline & 13 & Cold Night Index \\
\hline (4) & 15,6 & Cold Night Index \\
\hline & 2007 & Huglin \\
\hline & 10,0 & Temperature \\
\hline & 1541 & Huglin \\
\hline & 15 & Day \\
\hline & 13,5 & Cold Night Index \\
\hline & 184 & Dryness Index \\
\hline
\end{tabular}

CoGui

Fig. 7. An example of numerical data.

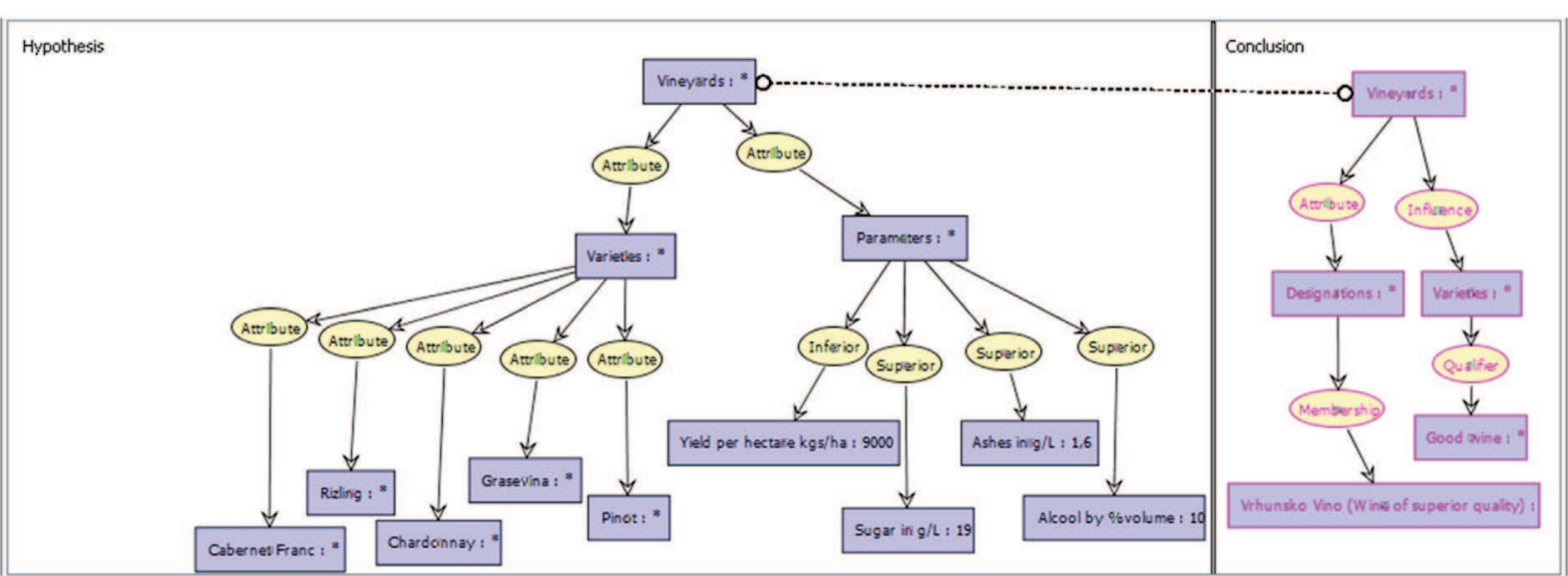

Fig. 8. An example of graph rules (Vhrunsko Vino region B). 


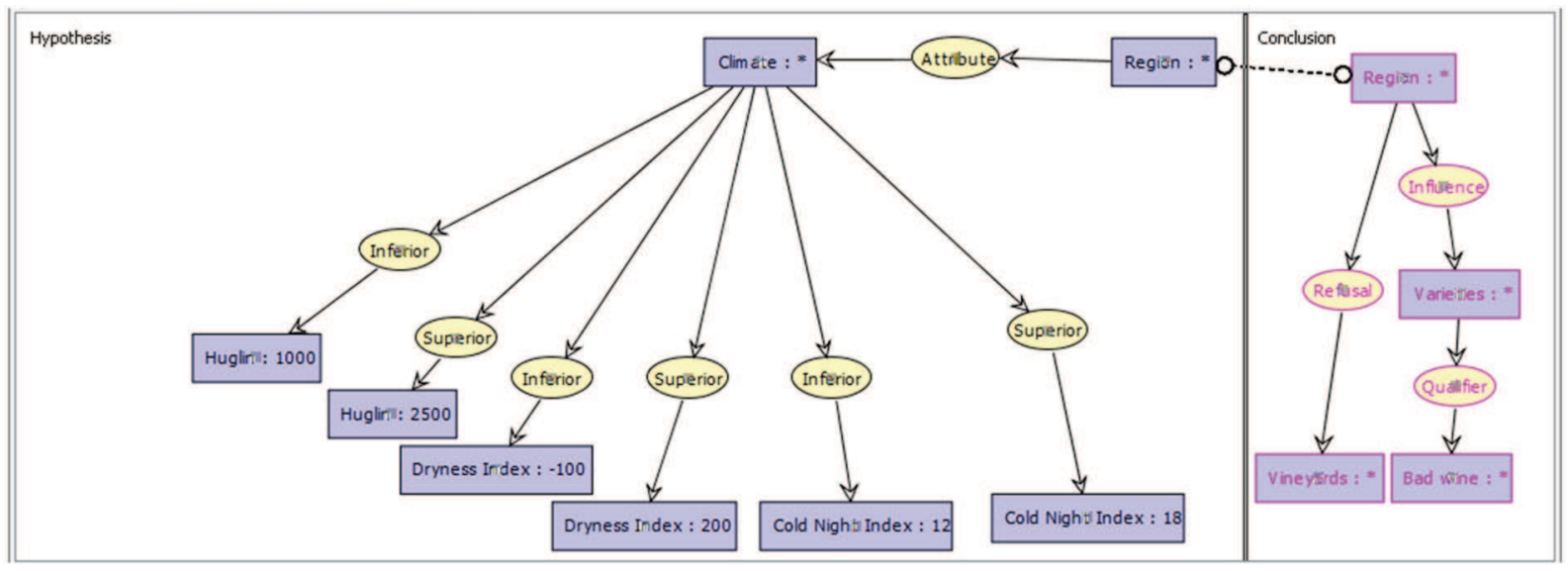

Fig. 9. An example of graph rules combining indexes.

The numerical values (see Fig. 7) of data are added to precise the descriptions of modeled rules and facts. These data are associated to the value of viticultural climatic indexes (Dryness Index, Huglin Index, and Cold Night Index).

\subsection{Graph rules}

- Regarding the rules, their solicitation triggers the verification of properties in the contextual application and places the results in the knowledge base.

- In terms of designations, four appellations are registered: Istrian Quality (wine of protected origin with a base-line style and a guarantee of quality), Stolno vino (table wine), Kvalitetno vino (quality wine) and Vhrunsko vino (superior quality wine).

- These three designations are based on a specific legislation issued by the Ministry of Agriculture and Forestry referring to the law on wine. This text translated as "Regulations on wine" was published in 1996 in the official journal. This law defined three geographical designations of origin and quality.

- It divides Croatia into regions and sub-regions and performs four classes: the first zone B comprises the following sub-regions:
Moslavina Varazdin, Plešivica, Zagorje-Medjimurje; the second zone C1 includes these sub-regions: the Danube, Slavonia; the third zone C2 comprises the sub-regions: Istria, Croatian coast and hinterland; and the fourth zone C3 includes sub-regions: North, Central, and South Dalmatia. The information processing will recommend some varieties depending on the ability of each area to produce a wine of superior quality (Vino Vhrunsko) and to produce a quality wine (Vino Kvalitetno). So, it will involve the performance of the parcel in kilograms of grapes per hectare, which again varies by class for one of the three designations. Also according to each area and quality, the sugar rate must be determined in $\mathrm{g} / \mathrm{l}$, alcohol rate in \% volume and ash content (wood residues) in $\mathrm{g} / \mathrm{l}$.

We can see below two examples of conceptual graph rules modeled in the CoGui software (see Figs. 8 and 9). In these figures the hypothesis of the rules is described in the left part and the consequence of the rule is described in the right part.

Through these rules, we see the authorized varieties and required conditions to trigger the application of the rule. In the right part, the findings of the rule application are shown in purple color: if the studied

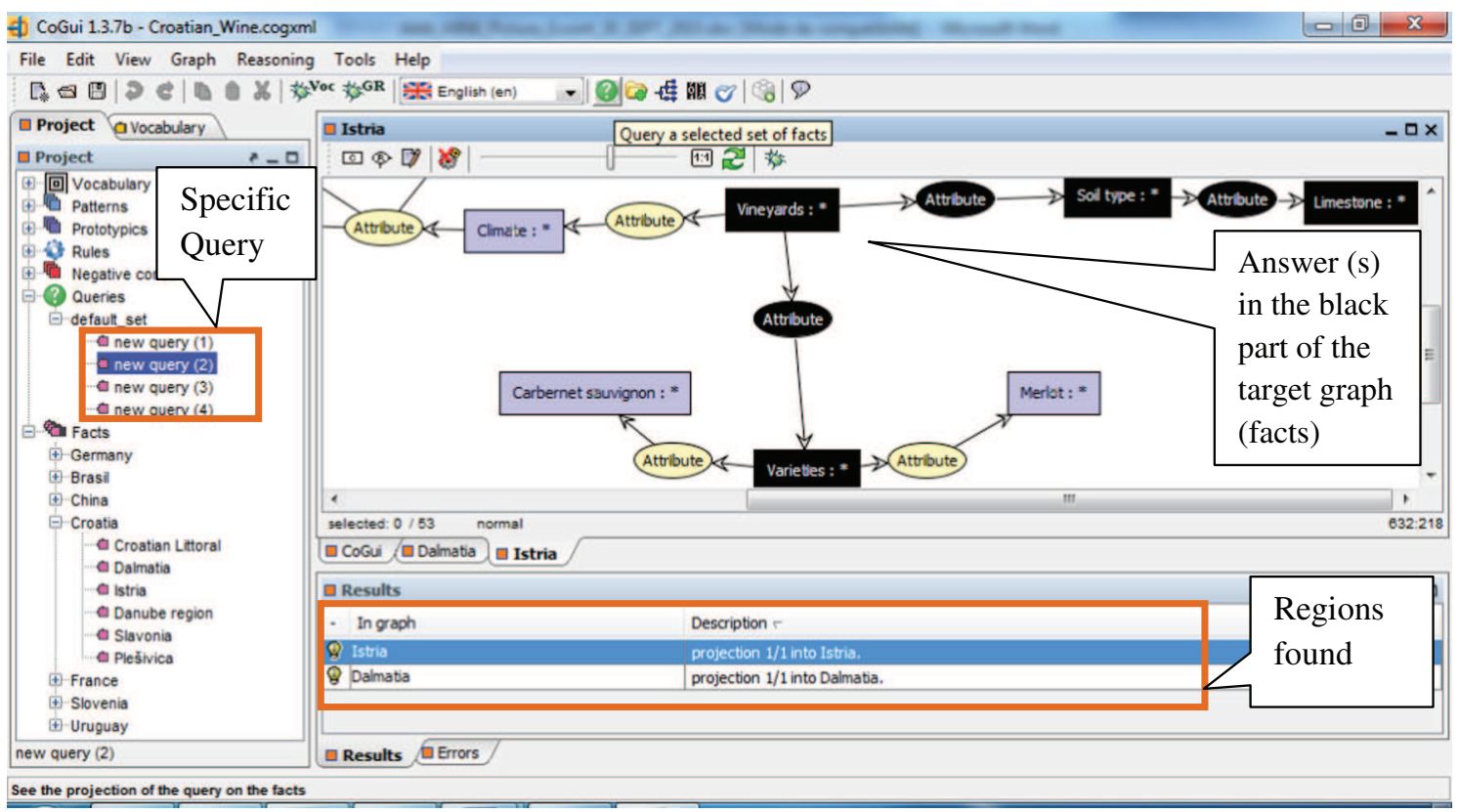

Fig. 10. An example of reasoning with query in the left frame and its answer (black sub graph) in the right frame. 
Results of reasoning procedures on Croatian viticulture.

\begin{tabular}{|c|c|c|c|c|}
\hline Croatian Regions & & Similar regions & Typical varieties & International varieties \\
\hline \multirow{16}{*}{$\begin{array}{l}\text { Croatian Coastal } \\
\text { Region }\end{array}$} & \multirow[t]{3}{*}{ Southern Dalmatia } & California (United States of America) & Red variety (Plavac Mali) & \multirow[t]{3}{*}{ White variety (Malvasia) } \\
\hline & & Apulia (Italy) & White varieties (Pošip, Grk, & \\
\hline & & Las Brujas (Uruguay) & Maraština or Rukatac) & \\
\hline & \multirow[t]{3}{*}{ Central Dalmatia } & Styria (Austria) & Red variety (Plavac mali) & \multirow[t]{3}{*}{ Red variety (Zinfandel) } \\
\hline & & South Moravian (Czech Republic) & White variety (Vugava) & \\
\hline & & Lower Styrian (Slovenia) & & \\
\hline & \multirow[t]{2}{*}{ Northern Dalmatia } & Rhone valley (France) & Red varieties (Plavina, Babić, Lasina) & \multirow[t]{2}{*}{ Red varieties (Merlot, Syrah, Grenache) } \\
\hline & & Aragon (Spain) & White varieties (Maraština, Debit) & \\
\hline & \multirow[t]{2}{*}{ Dalmatian Zagora } & Livno (Bosnia and Herzegovina) & Red variety (Trnjak) & \multirow[t]{2}{*}{ Red variety (Merlot) } \\
\hline & & & White variety (Kujundžuša) & \\
\hline & \multirow[t]{4}{*}{ Croatian Littoral } & Maja Briaset (Albania) & White varieties (Žlahtina, Gegić) & \multirow[t]{4}{*}{ White variety (Sauvignon blanc) } \\
\hline & & Orjen (Montenegro) & & \\
\hline & & Tara (Serbia) & & \\
\hline & & Gorjanci (Slovenia) & & \\
\hline & \multirow[t]{2}{*}{ Istria } & Trieste (Italy) & Red varieties (Teran) & \multirow[t]{2}{*}{ Red varieties (Merlot, Cabernet sauvignon) } \\
\hline & & Burgundy (France) & White varieties (Malvazija, Muškat) & \\
\hline \multirow{13}{*}{$\begin{array}{c}\text { Continental } \\
\text { Croatia }\end{array}$} & Danube region & Bačka Palanka (Serbia) & Red varieties (Frankovka) & Red varieties (Cabernet sauvignon, Merlot) \\
\hline & & & White varieties (Graševina, Traminac) & \\
\hline & \multirow[t]{2}{*}{ Slavonia } & Burgundy (France) & Red varieties (Frankovka) & $\begin{array}{l}\text { Red varieties (Merlot, Pinot noir, Cabernet } \\
\text { Sauvignon) }\end{array}$ \\
\hline & & California (United States of America) & $\begin{array}{l}\text { White varieties (Graševina, Silvanac } \\
\text { zeleni) }\end{array}$ & $\begin{array}{l}\text { White varieties (Chardonnay, Riesling, } \\
\text { Pinot Gris, Sauvignon blanc) }\end{array}$ \\
\hline & Moslavina & Tokaj-Hegyalja wine region (Hungary) & White varieties (Škrlet, Dišeća Ranina) & White varieties (Chardonnay, Pinot blanc) \\
\hline & \multirow[t]{2}{*}{ Plešivica } & Rheinhessen, Pfalz (Austria) & Red varieties (Portugizac) & Red varieties (Pinot noir) \\
\hline & & $\begin{array}{l}\text { Weinsberg (Germany) } \\
\text { Tarn (France) }\end{array}$ & $\begin{array}{l}\text { White varieties (Rajnski rizling or } \\
\text { Riesling) }\end{array}$ & White varieties (Sauvignon blanc, Chardonnay) \\
\hline & Međimurje and Varaždin & $\begin{array}{l}\text { Samos (Greece), Frontignan (France) } \\
\text { Piedmont (Italy) }\end{array}$ & White variety (Muškat žuti) & White variety (Sauvignon blanc) \\
\hline & \multirow{5}{*}{$\begin{array}{l}\text { Hrvatsko Zagorje and } \\
\text { Prigorje }\end{array}$} & Franconia (Germany), & White variety (Kraljevina) & \multirow[t]{5}{*}{ White varieties (Sylvaner, Pinot Blanc) } \\
\hline & & Transylvania (Romania) & & \\
\hline & & Alsace (France) & & \\
\hline & & Limbach (Slovakia) & & \\
\hline & & California (United States of America) & & \\
\hline
\end{tabular}

fact respects the hypotheses of that rule, the wine will be qualified with Vhrunsko Vino designation and considered as a potential good wine. Regarding the rules for the indexes, we informed the extreme values of the indexes so that if an index is below this threshold, it is excluded and the studied wine is considered as a bad wine.

Logical expression of the graph rule visualized in Fig. 8: $\exists x \exists y \exists z \exists m$ $\exists n \exists r \exists s \exists t$ (Vineyards $(x) \wedge$ Varieties $(y) \wedge$ Parameters $(z) \wedge$ Cabernet Franc $(m) \wedge$ Rizling $(n) \wedge$ Chardonnay $(r) \wedge$ Grasevina $(s) \wedge$ Pinot $(t) \wedge$ Yield per hectare $\mathrm{kgs} / \mathrm{ha}(9000) \wedge$ Sugar in $\mathrm{g} / \mathrm{L}(19) \wedge$ Ashes in $\mathrm{g} / \mathrm{L}(1,6) \wedge$ Alcool by \%olume $(10) \wedge$ Attribute $(x, y) \wedge$ Attribute $(x$, $z) \wedge$ Attribute $(y, m) \wedge$ Attribute $(y, n) \wedge$ Attribute $(y, r) \wedge$ Attribute $(y, s) \wedge$ Attribute $(y, t) \wedge$ Inferior $(z, 9000) \wedge$ Superior $(z, 19) \wedge$ Superior $(z, 1,6) \wedge$ Superior $(z, 10) \rightarrow \exists u \exists v \exists w$ (Vineyards $(x) \wedge$ Varieties $(y) \wedge$ Designations $(u) \wedge$ Good wine $(v) \wedge$ Vrhunsko Vino (Wine of superior quality $)(w) \wedge$ Attribute $(x, u)) \wedge$ Influence $(x, y) \wedge$ Membership $(u$, $w) \wedge$ Qualifier $(y, w))$

Logical expression of the graph rule visualized in Fig. 9: $\exists x \exists y$ (Region $(x) \wedge$ Climate $(y) \wedge$ Huglin (1000) ^ Huglin (2500) $\wedge$ Dryness Index $(-100) \wedge$ Dryness Index (200) ^ Cold Night Index (12) ^ Cold Night Index $(18) \wedge$ Attribute $(x, y) \wedge$ Inferior $(x, 1000) \wedge$ Superior $(x$, $2500) \wedge$ Inferior $(x,-100) \wedge$ Superior $(x, 200) \wedge$ Inferior $(x, 12) \wedge$ Superior $(x, 18) \rightarrow \exists u \exists v \exists w$ (Region $(x) \wedge$ Vineyards $(u) \wedge$ Varieties $(v) \wedge$ Bad wine $(w) \wedge$ Refusal $(x, u)) \wedge$ Influence $(v, w) \wedge$ Qualifier $(v, w))$

\subsection{Graph facts}

- The facts are built in the same way as the rules for one detail, but with one important difference: there is no conclusion.

- The facts are built according to their contents, and semantic features have to be analyzed in turn, first at the various levels, then as interwoven groups of regional situations. Indeed, the facts will serve as a basis when you want to ask a question (query). They are the factual knowledge of the basic elements of logical reasoning: what is the most suitable region or is there a region corresponding to a possible location of the vineyard?

- The facts established are related to the most notorious reputation in producing wines in Croatia. So each region contains varieties, dryness, Huglin and Cold Night Indexes, and soil types. Also, we indicate the regions with similarities to the Croatian regions for target indexes.

- Sometimes, the facts are structured according to regional areas with a fact for the designation and another one for each season. From our perspective, this is not an ideal way for the processing of queries with a variety of attributes in the CoGui software, since we can get a season or a corresponding name of a specific region, but this does not meet the criteria of other neighboring regions having potentially relevant information. In our case, if we have one group of facts by region with different sub-facts inside, then the software can detect the consistent matching to find similar interesting locations of the target region.

\subsection{Graph queries}

The general queries contain a list of relevant attributes such as meteorological factors, soil conditions, or crop requirements that are useful for viticulture. Questions are modeled in conceptual graph queries to provide visual answers using the projection operation. By inputting data such as the region, the designation, or the climatic indexes, the CoGui software automatically generates the possible corresponding answers for the specified requirements (see Fig. 10).

The reasoning is dynamic with visual sequences that allow an easy understanding of different processing steps. With this visual reasoning, we can know if there are similarities between the facts and specified queries, and some visual suggestions are provided with arguments (Doumbouya et al., 2015a; Doumbouya et al., 2015b; Doumbouya et 
al., 2015c; Doumbouya et al., 2015d) that underline the part of facts which allow or not to obtain the desired results. The results of reasoning procedures with some Croatian regions are described in Table 2 (Croatia boasts a variety of vine growing regions, from Mediterranean glowing heat to cold slopes of the Alps (Špiranec, 2011) . In the continental Croatia, western areas are appropriate for the cultivation of aromatic varieties (e.g. Sauvignon, Muscat a Petit Grain and Riesling) and the eastern areas are ideal for the cultivation of aromatic varieties and yield wines of the highest quality (e.g. Pinot Noir, Graševina, Merlot, Syrah and Grenache). In the Croatian Coastal Region, vine varieties vary widely with the warmest area producing stronger wines (e.g. Plavac Mali and Babić) and the colder area producing aromatic wines with a refreshing character (e.g. Chardonnay and Malvazija Istarska)).

\section{Conclusion}

Throughout an integrated numerical and symbolic framework, we provide a formal visual reasoning process with the aim of highlighting the rich identity card of the Croatian vineyard and strategic options for its international development. After careful consideration and detailed study of wine regions of Croatia, we developed a mapping of Croatian viticultural settings with the identification of different varieties present both autochthonous and classic features and key designations.

In order to find similarities between these regions and varieties with other regions of the world, a multicriteria climatic analysis was developed. The numerical reasoning is implemented with the MCC software through calculations based on three climatic indexes complementary to each other and their combination ensures that the targeted analysis can be effectively accomplished. A symbolic reasoning is deployed through the CoGui software, which allowed us to establish a knowledge base with visual operations displaying the similarities or not between viticultural regions. It will be useful to incorporate other web-based tools that can help non experts in visual identification of critical information in vineyard monitoring (Pertot et al., 2012).

In order to achieve climate analysis, some data require a contact with government agencies on the federal, provincial/ territorial, and municipal level to determine the regulatory agency and applicable regulations governing the viticulture sector. It is also clear that the domain of the wine production is very complex and requires consideration of many different activities in the process (harvesting and destemming, crushing and fermentation, laboratory tests, blending and fining, preservatives, and filtration) (Gómez-Plaza and Cano-López, 2011; Urtubia et al., 2007). In addition, the used climatic and geologic factors are certainly adequate, but it still lacks some factors such as complete consideration of wind and landscape transformations (Papadimitriou, 2012) (e.g. the slope of the land down to the water or shoreline).

In a context of wine market globalization, the theme of geographical diversity and identity has a growing importance. Countries that are endowed with some agricultural areas connecting the culture and the heritage of the lands have traditional and significant assets to meet the challenges of our globalized world. The domain features of specific lands provide many advantages that will help them ensure the sustainable preservation of their activities and development in an evolving market driven by users. From that perspective, national cooperatives constitute one of the pillars of agricultural policy to ameliorate the performance and competitiveness of producers in the dynamic market organization. Croatian land is therefore suitable for its vineyards having earned specific designations that can offer an effective economic energy to the national agricultural policy.

The continuous improvement of the wine production activities of the Croatian agricultural regions under identifiable product is expected to lead to a better-quality visibility of the wine production activities. As demonstrated by the variety labels which refer to specific Croatian agricultural regions, it should be noted that its viticulture shares certain common characteristics with recognized European brand names, for a broader market.

\section{References}

Baget, J.F., Mugnier, M.L., 2002. Extensions of simple conceptual graphs: the complexity of rules and constraints. J. Artif. Intell. Res. 16, 425-465.

Baget, J.F., Leclère, M., Mugnier, M.L., Salvat, E., 2011. On rules with existential variables: walking the decidability line. Artif. Intell. 175 (9-10), 1620-1654 (June).

Bojnec, S. 2011. Land Markets in the EU Candidate Countries of Croatia, Former Yugoslav Republic of Macedonia and Turkey. Factor Markets Working Paper No. 1. Centre for European Policy Studies, Brussels.

Carloni, O., Leclère, M., Mugnier, M.-L., 2009. Introducing reasoning into an industrial knowledge management tool. Appl. Intell. 31, 211-224.

Charters, Steve, 2006. Chapter 2 - The history of wine. Wine and Society 10-45.

Chein, M., Mugnier, M.L., 2008. Graph-based knowledge representation : computational foundations of conceptual graphs. Series: Advanced Information and Knowledge Processing. Springer, London (United Kingdom) (445 pp., ISBN 978-1-84800-285-2, October).

Deloire, A., Carbonneau, A., Wang, Z., Ojeda, H., 2004. Vine and water: a review. J. Sci. Vigne Vin 38 (1), 1-13.

Doumbouya, Mamadou Bilo, Kamsu-Foguem, Bernard, Kenfack, Hugues, Foguem, Clovis, 2015a. Combining conceptual graphs and argumentation for aiding in the teleexpertise. Comput. Biol. Med. 63, 157-168 (1 August).

Doumbouya, Mamadou Bilo, Kamsu-Foguem, Bernard, Kenfack, Hugues, Foguem, Clovis, 2015b. A framework for decision making on teleexpertise with traceability of the reasoning. IRBM 36 (1), 40-51 (February).

Doumbouya, Mamadou Bilo, Kamsu-Foguem, Bernard, Kenfack, Hugues, Foguem, Clovis, 2015c. Argumentation semantics and graph properties. Inf. Process, Manag. http:/ dx.doi.org/10.1016/j.ipm.2015.08.003.

Doumbouya, Mamadou Bilo, Kamsu-Foguem, Bernard, Kenfack, Hugues, Foguem, Clovis, 2015d. Argumentative reasoning and taxonomic analysis for the identification of medical errors. Eng. Appl. Artif, Intell. http://dx.doi.org/10.1016/j.engappai.2015.08. 009.

Ellison, Patricia, Ash, Gavin, McDonald, Craig, 1998. An expert system for the management of Botrytis cinerea in Australian vineyards. I. Development. Agric. Syst. 56 (2) 185-207 (February).

Fernández-Mar, M.I., Mateos, R. García-Parrilla, M.C., Puertas, B. Cantos-Villar, E., 2012. Bioactive compounds in wine: resveratrol, hydroxytyrosol and melatonin: A review. Food Chem. 130 (4), 797-813 (15 February).

Genest, D., Chein, M.A., 2005. Content-search information retrieval process based on conceptual graphs. Knowl. Inf. Syst. 8, 292-309 (no. 3, Springer).

Gómez-Plaza, E., Cano-López, M., 2011. A review on micro-oxygenation of red wines: claims, benefits and the underlying chemistry. Food Chem. 125 (4), 1131-1140 (15 April)

Huglin, P., 1978. Nouveau mode d'évaluation des possibilités héliothermiques d'un milieu viticole. Symposium International sur l'Écologie de la Vigne, l, Constança, Roumanie, 1978. Ministère de l'Agriculture et de l'Industrie Alimentaire, pp. 89-98.

Jackson, Ron S., 2000. 9 - Specific and Distinctive Wine Styles. Wine Science, Second edition. Principles, Practice, Perception, pp. 434-481.

Kamsu Foguem, B., Coudert, T., Béler, C., Geneste, L., 2008. Knowledge formalization in experience feedback processes: an ontology-based approach. Comput. Ind. 59 (7), 694-710 (September)

Kamsu-Foguem, Bernard, 2012. Knowledge-based support in non-destructive testing for health monitoring of aircraft structures. Adv. Eng. Inform. 26 (4), 859-869 (October).

Kamsu-Foguem, Bernard, 2014. Ontological view in telemedicine. Eur. Res. Telemed. (La Recherche Européenne en Télémédecine) 3 (2), 67-76 (June).

Kamsu-Foguem, Bernard, Flammang, Aurélie, 2014. Knowledge description for the suitability requirements of different geographical regions for growing wine. Land Use Policy 38C, 719-731.

Kamsu-Foguem, Bernard, Henry Abanda, Fonbeyin, 2015. Experience modeling with graphs encoded knowledge for construction industry. Comput. Ind. 70, 79-88 (June).

Kamsu-Foguem, Bernard, Noyes, Daniel, 2013. Graph-based reasoning in collaborative knowledge management for industrial maintenance. Comput. Ind. 64 (8), 998-1013 (October).

Kamsu-Foguem, Bernard, Rigal, Fabien, Mauget, Félix, 2013a. Mining association rules for the quality improvement of the production process. Expert Syst. Appl. 40 (4), 1034-1045 (March).

Kamsu-Foguem, Bernard, Diallo, Gayo, Foguem, Clovis, 2013b. Conceptual graph-based knowledge representation for supporting reasoning in african traditional medicine. Eng. Appl. Artif. Intell. 26 (4), 1348-1365 (April).

Kamsu-Foguem, Bernard, Tchuenté-Foguem, Germaine, Foguem, Clovis, 2014a. Verifying a medical protocol with temporal graphs: the case of a nosocomial disease. J. Crit. Care 29 (4), 690.e1-690.e9 (August).

Kamsu-Foguem, Bernard, Tchuenté-Foguem, Germaine, Foguem, Clovis, 2014b. Conceptual graph operations for formal visual reasoning in the medical domain. IRBM 35 (5), 262-270 (October).

Kamsu-Foguem, Bernard, Tchuenté-Foguem, Germaine, Foguem, Clovis, 2014c. Using conceptual graphs for clinical guidelines representation and knowledge visualization. Inf. Syst. Front. 16 (4), 571-589 (September).

Kamsu-Foguem, B., Tiako, P.F., Mutafungwa, E., Foguem, C., 2015. Knowledge-based modelling applied to synucleinopathies. Eur. Geriatr. Med. 6 (4), 381-388 (July).

Kanianska, Radoslava, Kizeková, Miriam, Novácek, Jozef, Zeman, Martin, 2014. Land-use and land-cover changes in rural areas during different political systems: a case study of Slovakia from 1782 to 2006. Land Use Policy 36, 554-566.

Lerman, Z., Csaki, C., Feder, G., 2002. Land policies and evolving farm structures in transition countries. Policy Research Working Paper No. 2794. World Bank, Washington, DC 
Lorenz, D.H., Eichhorn, K.W., Bleiholder, H., Klose, R., Meier, U., Weber, E., 1995. Phenological growth stages of thegrapevine (Vitis vinifera L. ssp. vinifera) - codes anddescriptions according to the extended BBCH scale. Aust. J. Grape Wine Res. 1, $100-110$.

Nicholas, Kimberly A., Durham, William H., 2012. Farm-scale adaptation and vulnerability to environmental stresses: insights from winegrowing in Northern California. Glob. Environ. Chang. 22 (2), 483-494 (May).

Paoli, J.-N., Strauss, O., Tisseyre, B., Roger, J.-M., Guillaume, S., 2007. Spatial data fusion for qualitative estimation of fuzzy request zones: application on precision viticulture. Fuzzy Sets Syst. 158 (5), 535-554 (1 March).

Papadimitriou, Fivos, 2012. Artificial Intelligence in modelling the complexity of Mediterranean landscape transformations. Comput. Electron. Agric. 81, 87-96 (February).

Pertot, Ilaria, Kuflik, Tsvi, Gordon, Igor, Freeman, Stanley, Elad, Yigal, 2012. Identificator: a web-based tool for visual plant disease identification, a proof of concept with a case study on strawberry. Comput. Electron. Agric. 84, 144-154 (June).

Pinney, Thomas, 2012. The Makers of American Wine: A Record of Two Hundred Years. University of California Press, Berkeley, CA.

Potes Ruiz, Paula Andrea, Kamsu-Foguem, Bernard, Noyes, Daniel, 2013. Knowledge reuse integrating the collaboration from experts in industrial maintenance management. Knowl. Based Syst. 50, 171-186 (September).

Potes Ruiz, Paula, Kamsu Foguem, Bernard, Grabot, Bernard, 2014. Generating knowledge in maintenance from Experience Feedback. Knowl.-Based Syst. 68, 4-20 (September).

Ripoche, Aude, Rellier, Jean-Pierre, Martin-Clouaire, Roger, Paré, Nakié, Biarnès, Anne, Gary, Christian, 2011. Modelling adaptive management of intercropping in vineyards to satisfy agronomic and environmental performances under Mediterranean climate. Environ. Model Softw. 26 (12), 1467-1480 (December).

Ruml, Mirjana, Vuković, Ana, Vujadinović, Mirjam, Djurdjević, Vladimir, Ranković-Vasić, Zorica, Atanacković, Zoran, Sivčev, Branislava, Marković, Nebojša, Matijašević, Saša, Petrović, Nevena, 2012. On the use of regional climate models: implications of climate change for viticulture in Serbia. Agric. For. Meteorol. 158-159, 53-62 (15 June).

Russell, G., Muetzelfeldt, R.I., Taylor, K., Terres, J.-M., 1999. Development of a crop knowledge base for Europe. Eur. J. Agron. 11, 187-206 (November).

Sablayrolles, J.M., 2009. Control of alcoholic fermentation in winemaking: current situation and prospect. Food Res. Int. 42 (4), 418-424 (May).

Sene, Alsane, Kamsu-Foguem, Bernard, Rumeau, Pierre, 2015. Telemedicine Framework using Case-based Reasoning with Evidences. Comput. Methods Prog. Biomed. 121 (1), 21-35 (August).

Špiranec, Saša, 2011. Wines of Croatia: unique and exciting. Publisher: Croatian Chamber of Economy, for the publisher Vidošević, Nadan, CCE President, Zagreb, (May). Available online at: https://www.bluedanubewine.com/pdf/Wines_of_Croatia.pdf (last accessed September 25, 2015)

Sowa, J. 1984. Conceptual structures: information processing in mind and machine. The Systems Programming Series (Hardcover). Addison-Wesley Longman Publishing Co., Inc, Boston, Massachusetts, USA, p. 481.

Sowa, J.F., 2000. Knowledge Representation: Logical, Philosophical and computational Foundations. Brooks Cole Publishing $\mathrm{Co}$.

Thomopoulos, Rallou, Buche, Patrice, Haemmerlé, Ollivier, 2003. Representation of weakly structured imprecise data for fuzzy querying. Fuzzy Sets Syst. 140 (1), 111-128 (16 November)

Thomopoulos, Rallou, Destercke, Sébastien, Charnomordic, Brigitte, Johnson, Iyan, Abécassis, Joël, 2013. An iterative approach to build relevant ontology-aware datadriven models. Inf. Sci. 221, 452-472 (1 February).
Tonietto, J. 1999. Les macroclimats viticoles mondiaux et l'influence du mésoclimat sur la typicité de la Syrah et du Muscat de Hambourg dans le sud de la France : méthodologie de caractérisation (Thèse Doctorat), École Nationale Supérieure Agronomique de Montpellier - ENSA-M (233p).

Tonietto, J., Carbonneau, A., 2004. A multicriteria climatic classification system for grapegrowing regions worldwide. Agric. For. Meteorol. 124/1-2, 81-97.

Urtubia, Alejandra, Ricardo Pérez-Correa, J., Soto, Alvaro, Pszczólkowski, Philippo, 2007. Using data mining techniques to predict industrial wine problem fermentations. Food Control 18 (12), 1512-1517 (December).

Zavaglia Torres, Tércia, Pierozzi Jr., Ivo, Rodrigues Pereira, Nadir, de Castro, Alexandre, 2011. Knowledge management and communication in Brazilian agricultural research: An integrated procedural approach. Int. J. Inf. Manag. 31 (2), 121-127 (April).

Bernard Kamsu-Foguem: He has a PhD in Computer Science and Engineering from the University of Montpellier 2 in 2004. He got the "accreditation to supervise research", abbreviated HDR from University of Toulouse in 2013. He has obtained the status of Visiting Professor at international universities: United Kingdom (e.g. Oxford Brookes University, Oxford), and Finland (e.g. Aalto University, Helsinki University of Technology, VTT Technical Research Centre of Tampere, University of Oulu, Åbo akademi of Turku University). His current interests are in Knowledge Discovery and Data Mining Knowledge Representation, Formal Visual Reasoning, Ontology-based Semantic Analysis, Knowledge Exploitation for remote Collaboration, Decision Support Systems and Intelligent Systems. Application domains include industrial Continuous Improvement processes, Telemedicine services and Health Information Systems. He is a reviewer for large number of international scientific journals such as Computers in Biology and Medicine, Knowledge Management Research \& Practice, Interacting with Computers, Sensors, Engineering Applications of Artificial Intelligence and Knowledge-Based Systems $\mathrm{He}$ is a member of the thematic group: e-Health of InterOP-VLab (International Virtual Laboratory for Enterprise Interoperability).

Aurélie Flammang: She graduated in wine business from Université du vin de Suze-LaRousse (southeastern France) in 2008. She is passionate about the wine field from the land to the commercialization. She already contributed to the publication of a scientist report of knowledge description for the suitability requirements of different geographical regions for growing wine in China. She is specialized in opening-market for foreign and domestic beverages. She travels often all around the world to meet people who are at the root of the products to experience total immersion in their natural environment. Her interest is also focused on social and cultural aspects. She has been a wine writer in one of the most influential French gastronomic guide Gault et Millau.

Germaine Tchuenté-Foguem: She has a Master of Advanced Studies from the University of Yaoundé I (Cameroon) in 2007, in the domain of synchronization in dynamic distributed systems. She has a Research Master in automatic and decisional systems obtained in 2010 from ENIT-INPT of Tarbes (France) on Fuzzy logic in competence management. She is preparing a $\mathrm{PhD}$ thesis focused on a knowledge-based information system for visual support in critical decision-making. She currently takes an active interest in Computer information system(s) (e.g. algorithmic processes), information and communication technology, Data Warehouse, Data mining (Sequential rule mining, Sequential pattern mining or Association rule mining), Knowledge acquisition and Knowledge discovery. 